\title{
ACESSO À JUSTIÇA E CIDADANIA
}

\author{
JOSÉ AFONSO DA SILVA*
}

1 - Introdução. 2 - Cidadania e seus direitos. 3 - Acesso à Justiça. 4 - Justiça igual para todos. 5 - Acesso à Justiça e organização judiciária. 6 - Pontos da reforma judiciária. 7. Conclusão.

\section{1 - Introdução}

1. Acesso à Justiça é uma expressão que significa o direito de buscar proteção judiciária, o que vale dizer: direito de recorrer ao Poder Judiciário em busca da solução de um conflito de interesse. Nessa acepção, a expressão acesso à Justiça tem um sentido institucional. Essa é a significação que se acha no inc. XXXV do art. 5o da Constituição, quando diz que "a lei não poderá excluir da apreciação do Poder Judiciário lesão ou ameaça a direito". Mas, se o acesso à Justiça se resumisse apenas nessa acepção institucional, seu significado seria de enorme pobreza valorativa. Veremos adiante que mesmo a norma constitucional contida no citado inc. XXXV não se resume nessa fórmula de pouca expressividade normativa. É que, na verdade, quem recorre ao Poder Judiciário é que confia em que ele é uma instituição que tem por objeto ministrar Justiça como valor, uma instituição que, numa concepção moderna, não deve nem pode satisfazer-se com a pura solução das lides, de um ponto de vista puramente processual. Os fundamentos constitucionais da atividade jurisdicional querem mais, porque exigem que se vá a fundo na apreciação da lesão ou ameaça do direito para efetivar um julgamento justo do conflito. Só assim se realizará a Justiça concreta que se coloca precisamente quando surgem conflitos de interesses, como lembra Kelsen: "E somente onde existem tais conflitos de interesses a justiça se torna um problema. Onde não há conflitos de interesses, não há necessidade de justiça."

1 Cf. $O$ que é justiça? p. 4. trad. de Luís Carlos Borges.

* Prof. Tit. aposentado da FDUSP.

\begin{tabular}{lll}
\hline R. Dir. Adm., & Rio de Janeiro, 216: 9-23, & abr./jun. 1999 \\
\hline
\end{tabular} 
2. Se o Poder Judiciário é um dos Poderes do Estado. como enuncia o art. $2^{\mathrm{o}}$ da Constituição. e se o Estado, República Federativa do Brasil. tem como um de seus primeiros fundamentos construir uma sociedade justa, então não pode mais ele se contentar com a mera solução processual dos conflitos. Cada sentença há que constituir um tijolo nessa construção da sociedade justa. E a Justiça aqui há de ser aquele valor supremo de uma sociedade fraterna, pluralista e sem preconceito que nos promete o Preâmbulo da Constituição. Montesquieu já dizia que não haveria liberdade se o poder de julgar não fosse separado dos outros Poderes. ${ }^{2}$ Hoje, quer-se muito mais do Poder Judiciário, requer-se que ele seja efetivo guardião dos direitos fundamentais da pessoa humana, sem o que a Justiça não se realizará.

3. E aqui é que entra o outro tema desta exposição: a cidadania. É o que examinaremos sinteticamente em seguida, para depois aprofundarmos a questão do acesso à Justiça.

\section{2 - Cidadania e seus direitos}

4. Uma idéia essencial do conceito de cidadania consiste na sua vinculação com o princípio democrático. Por isso, pode-se afirmar que, sendo a democracia um conceito histórico que evolui e se enriquece com o evolver dos tempos, assim também a cidadania ganha novos contornos com a evolução democrática. É por essa razão que se pode dizer que a cidadania é o foco para onde converge a soberania popular.

O primeiro aspecto que nos chama a atenção no seu conceito é o da cisão que o discurso jurídico burguês fez entre o "homem" e o "cidadão", que refletiu na famosa Declaração de Direitos de 1789, que se chamou Declaração dos Direitos do Homem e do Cidadão, na qual a expressão Direitos do Homem denota o conjunto dos direitos individuais, pois ela é profundamente individualista, assinalando à sociedade um fim que é o de servir aos indivíduos, enquanto a expressão Direitos do Cidadão significa o conjunto dos direitos políticos de votar e ser votado, como institutos essenciais à democracia representativa. E esta foi a primeira manifestação da cidadania que qualifica os participantes da vida do Estado - o Cidadão, indivíduo dotado do direito de votar e ser votado - , oposta à idéia de vassalagem tanto quanto a de soberania aparece em oposição à de suserania. Surge, porém, uma nova dimensão da cidadania que decorre da idéia de Constituição dirigente, que não é apenas um repositório de programas vagos a serem cumpridos, mas constitui um sistema de previsão de direitos sociais, mais ou menos, eficazes, em torno dos quais é que se vem construindo a nova idéia de cidadania.

E essa nova idéia de cidadania se constrói, pois, sob o influxo do progressivo enriquecimento dos direitos fundamentais do homem. A Constituição de 1988, que assume as feições de uma constituição dirigente, incorporou essa nova dimensão da cidadania, quando, no seu art. $1^{0}$, inciso II, a indica como um dos fundamentos do Estado Democrático de Direito em que é constituída a República Federativa do 
Brasil. ${ }^{3}$ Cidadania está aqui num sentido mais amplo do que o de titular de direitos políticos. Qualifica os participantes da vida do Estado, o reconhecimento dos indivíduos como pessoa integrada na sociedade estatal (art. 50, LXXVII). Significa aí, também, que o funcionamento do Estado estará submetido à vontade popular. E aí o termo vincula-se com o conceito de soberania popular (parágrafo único do art. $1^{\circ}$ ), com os direitos políticos (art. 14) e com o conceito de dignidade da pessoa humana (art. $1^{\mathbf{0}}$, III), com os objetivos da educação (art. 205), como base e meta essenciais do regime democrático. ${ }^{4}$

A cidadania, assim considerada, consiste na consciência de pertinência à sociedade estatal como titular dos direitos fundamentais, da dignidade como pessoa humana, da integração participativa no processo do poder com a igual consciência de que essa situação subjetiva envolve também deveres de respeito à dignidade do outro, de contribuir para o aperfeiçoamento de todos.

Essa cidadania é que requer providências estatais no sentido da satisfação de todos os direitos fundamentais em igualdade de condições. Se é certo que a promoção dos direitos sociais encontra, no plano das disponibilidades financeiras, notáveis limites, menos verdade não há de ser que, inclusive em épocas de recessão econômica, o princípio da igualdade continua sendo um imperativo constitucional, que obriga a repartir também os efeitos negativos de todo periodo de crise. ${ }^{5}$

5. Ora, dentre os direitos fundamentais da pessoa humana sobreleva o direito que todos têm à jurisdição. Bem o diz o art. 10 da Declaração Universal dos Direitos Humanos: "Toda pessoa tem direito, em plena igualdade, a uma audiência justa e pública por parte de um tribunal independente e imparcial, para decidir de seus direitos e deveres ou do fundamento de qualquer acusação criminal contra ela". Essa norma integra nosso ordenamento constitucional por força do $\S 2^{\varrho}$ do art. $5^{\varrho}$ da Constituição, quando estabelece que os direitos e garantias expressos nela não excluem outros decorrentes do regime e dos princípios por ela adotados, ou dos tratados internacionais em que a República Federativa do Brasil seja parte. Com isso, ganha nova dimensão o art. $5^{\circ}, \mathrm{XXXV}$, da nossa Constituição, quando reconhece esse direito, ao declarar que a lei não excluirá da apreciação do Poder Judiciário lesão ou ameaça a direito.

3 Não se pode ignorar o fato de que a Constituiçāo de 1988, também, menciona a cidadania no sentido estrito tradicional de titular de direitos políticos. Assim é quando diz que compete à Uniāo legislar sobre nacionalidade, cidadania e naturalização (art. 22, XIII). Nesse contexto, quer-se dizer que compete à União legislar sobre os direitos políticos. A idéia, contudo, já fica mais confüsa com o emprego do termo no inc. II do $\S 1^{\mathfrak{Q}}$ do art. 68 , quando exclui do âmbito da delegação legislativa a legislaçāo sobre "nacionalidade, cidadania, direitos individuais, políticos e eleitorais", já que aí se excluem, separadamente, cidadania e direitos políticos, dando a entender que aquela é diverso destes. A impropriedade se agrava quando também fala em "direitos políticos e eleitorais", como se estes não fossem partes daqueles. Também a palavra cidadão, indicativa da legitimidade para propor a açāo popular (art. $5^{\mathfrak{l}}, \mathrm{LXXIII),}$ sempre foi tomada no sentido estrito de nacional no gozo dos direitos políticos.

4 Cf. nosso Curso de Direito Constitucional Positivo, 16 ed., p. 108.

5 Cf. ainda José Luis Cascajo Castro, trabalho citado, p. 26. 
6. O acesso à Justiça, como dissemos no início desta exposição, é uma garantia constitucional consubstanciada no inc. XXXV do art. $5^{\underline{o}}$ de nossa Carta Magna. Mas como também dissemos que o acesso à Justiça não se resume na mera faculdade de recorrer ao Poder Judiciário, desse mesmo dispositivo emana o princípio da proteção judiciário, mais rico de conteúdo valorativo, porque constitui a principal garantia dos direitos subjetivos. Mas ele, por seu turno, fundamenta-se no princípio da separação de poderes, reconhecido pela doutrina como garantia das garantias constitucionais, enquanto poder que detém o monopólio da jurisdição. Aí se junta uma constelação de garantias: as da independência e imparcialidade do juiz, a do juiz natural ou constitucional, a do direito de ação e de defesa, manifestação do direito fundamental à jurisdição, lembrado acima. Tudo ínsito nas regras do art. $5^{\circ}, \mathrm{XXXV}$, LIV e LV. ${ }^{6}$

7. Analisemos o citado art. $5^{9}$, inc. XXXV. Declara ele o seguinte: a lei não excluirá da apreciação do Poder Judiciário lesão ou ameaça a direito. Cármen Lúcia Antunes Rocha censura, com razão, a fórmula indireta da regra que confere o direito à jurisdição pela via indireta da proibição de competência ao legislador infraconstitucional de dispor em sentido contrário, ${ }^{7}$ em lugar de assegurar o direito na formulação positiva e direta, como fazem as Constituições da Itália, da Alemanha, de Portugal e da Espanha e também a Declaração Universal dos Direitos Humanos. ${ }^{8}$ O princípio foi convertido em regra de direito positivo através do art. $141, \S 4^{0}$, da Constituição de 1946. Não figurou nas constituições anteriores, não que o direito à jurisdição não fosse um princípio constitucional desde a Constituição do Império,

6 Garante-se no texto o processo, que envolve o direito à açāo, o direito de defesa, o contraditório, a isonomia processual e a bilateralidade dos atos procedimentais. Cf. Frederico Marques, "O artigo 141, $\S 4^{\circ}$, da Constituição Federal", Revista da Faculdade de Direito da Universidade do Ceará, n. 16, p. 65 e ss., dez./62, refere-se à Constituição de 1946, mas com ensinamento válido ainda; idem, A Reforma do Poder Judiciário, pp. 69 e ss.; Ada Pellegrini Grinover, ob. cit., tít. III; Kazuo Watanabe, ob. cit.; Luigi Paolo Comoglio, La garanzia costituzionale dell'azione ed il processo civile, Padova, CEDAM, 1970; Vicenzo Vigoritti, Garanzie costituzionale del processo civile, Milano, Giuffrè, 1973; Nicolò Trocer, Processo civile e costituzionale, Milano, Giuffrè, 1974, trad. de Gian Antonio Micheli.

7 Cf. "O direito constitucional à jurisdição", in Sálvio de Figueiredo Teixeira (coord.), As garantias do cidadão na justiça, p. 49.

8 Itália, art. 24: "Tutti possono agire in giudizio per la tutela dei propri diritti e interessi legitimi"; Alemanha, art. 103, 1: "Todos têm o direito de serem ouvidos legalmente perante os tribunais"; Portugal, art. 20, 1: "A todos é assegurado o acesso ao direito e aos tribunais para defesa dos seus direitos e interesses legítimos, não podendo a justiça ser denegada por insuficiência de meios econômicos"; Espanha, art. 24, 1: "Todas las personas tienen derecho a obtener la tutela efectiva de los jueces y tribunales en el ejercicio de sus derechos e intereses legítimos, sin que, en ningún caso, pueda producirse indefensión"; DUDH, art. 10: "Toda pessoa tem direito, em plena igualdade, a uma audiência justa e pública por parte de um tribunal independente e imparcial, para decidir de seus direitos e deveres ou do fundamento de qualquer acusação criminal contra ela", assim também o art. 14 do Pacto Internacional de Direitos Civis e Políticos, e mais o art. 18 da Declaração Americana dos Direitos e Deveres do Homem: "Toda pessoa pode recorrer aos tribunais para fazer respeitar os seus direitos", igualmente o art. $8^{\mathrm{o}} \mathrm{da}$ Convenção Americana sobre Direitos Humanos ("Pacto de San José de Costa Rica"). 
deduzível das normas de estruturação do Poder Judiciário. como lembrou Hermes Lima nos debates da Constituinte de 1946, em face da proposta segundo a qual "nenhum assunto relativo a direito poderá ser excluído do conhecimento do Poder Judiciário", ao que Mário Masagão objetou, conforme narra José Duarte, que Hermes Lima "se tornou avesso à realidade de algum tempo a esta parte, pois atravessou 15 anos a ver o Governo expedir decretos-leis, para impedir que o Judiciário tomasse conhecimento de vários assuntos, e agora quer suprimir o dispositivo pelo qual aquelas garantias, que nos faltavam, entrem para o texto constitucional". 9 O texto veio em forma negativa em reação ao modo usado (a lei, decreto-lei) para excluir da apreciação do Poder Judiciário lesão de direito. As reações ao arbítrio raramente vêm em forma positiva. As palavras da autora citada são justas, quando declara:

"Assim, historicamente se justifica o tratamento normativo constitucional oferecido ao tema, mas não o faz melhor dentre as possibilidades experimentadas no constitucionalismo contemporâneo. Quanto mais direta a norma, especialmente a constitucional, mais possibilidades tem ela de ter eficácia jurídica e social. Principalmente num país como o Brasil, em que a jurisdição não é nem mesmo agora vista tranqüilamente como o exercício regular e normal de um direito, preferindo-se, ainda, vislumbrá-la como uma afronta contra aquele que é convocado ao litígio judicial, a expressão constitucional que a positiva tem valor especial. Quanto mais invocado no texto da norma o titular do direito assegurado, tanto mais facilitado será o seu exercício e maior efetividade terá a norma, com as conseqüentes - e mesmo que implícitas - limitações de competências que lhe neguem a amplitude, dilua ou embarace a sua aplicação". ${ }^{10}$

8. Acrescenta-se ao texto, agora, também, a ameaça a direito, o que não é sem consequiência, pois possibilita o ingresso em juízo para assegurar direitos simplesmente ameaçados. Isso já se admitia, nas leis processuais, em alguns casos. A Constituição amplia o direito de acesso ao Judiciário, antes da concretização da lesão.

9. A primeira garantia que o texto revela é a de que cabe ao Poder Judiciário o monopólio da jurisdição, pois sequer se admite mais o contencioso administrativo que estava previsto na Constituição revogada. A segunda garantia consiste no direito de invocar a atividade jurisdicional sempre que se tenha como lesado ou simplesmente ameaçado um direito, individual ou não, pois a Constituição já não mais o qualifica de individual, no que andou bem, porquanto a interpretação sempre fora a de que o texto anterior já amparava direitos, por exemplo, de pessoas jurídicas ou de outras instituições ou entidades não individuais, e agora hão de levar-se em conta os direitos coletivos também.

10. $\mathrm{O}$ art. $5^{\circ}, \mathrm{XXXV}$, consagra, como dissemos, o direito de invocar a atividade jurisdicional, como direito público subjetivo. Não se assegura aí apenas o direito de agir, o direito de ação. Invocar a jurisdição para a tutela de direito é também direito daquele contra quem se age, contra quem se propõe a ação. Garante-se a plenitude

9 Cf. A Constituição brasileira de 1946, Exegese dos textos à luz dos trabalhos da Assembléia Constituinte, v. $3 / 16$ e 17

10 Cf. ob. cit., p. 49. 
da defesa. agora mais incisivamente assegurada no inciso LV do mesmo artigo: aos litigantes, em processo judicial e administrativo, e aos acusados em geral sāo assegurados o contraditório e ampla defesa, com os meios e recursos a ela inerentes. Agora a seguinte passagem do magistério de Liebman tem ainda maior adequação ao Direito Constitucional brasileiro:

"O poder de agir em juízo e o de defender-se de qualquer pretensão de outrem representam a garantia fundamental da pessoa para a defesa de seus direitos e competem a todos indistintamente, pessoa física e jurídica, italianos [brasileiros] e estrangeiros, como atributo imediato da personalidade, e pertencem por isso à categoria dos denominados direitos cívicos." 11

11. A apreciação da lesão ou ameaça de direito revela o conteúdo jurídico da norma do art. $5^{\circ}$, inc. XXXV. Que significa isso? O Poder Judiciário aprecia emitindo juízo de valor. "Apreciar" (de apreço, valor, dar valor) significa definir o valor que é tida alguma coisa. Quando isso é feito pelo Judiciário, o que se tem é um julgamento, pelo qual se decide o sentido do objeto sob apreciação. Logo, a apreciação da lesão ou ameaça de direito, pelo Poder Judiciário, se traduz numa decisão que define se houve ou não a lesão do direito, se há ou não a ameaça a direito alegado pela pessoa ou coletividade que recorreu ao Poder Judiciário. É no signo " apreciação" que se centra a garantia individual consubstanciada na norma constitucional. Bem o lembra, mais uma vez, Cármen Lúcia Antunes Rocha: "A apreciação não é mera referência constitucional, é direito fundamental individual e coletivo". Por isso, segundo ela, a "apreciação da lesão ou ameaça a direito alegado pela pessoa e encaminhada ao Poder Judiciário não se aperfeiçoa pela única repetição de uma decisão, independentemente do exame e julgamento de razões e fundamentos alegados pela parte". Isso ela o disse para mostrar que a súmula vinculante tolheria a apreciação do magistrado no sentido largo previsto constitucionalmente. ${ }^{12}$

É preciso repisar aqui a idéia, já lançada antes, de que o direito de acesso à justiça, consubstanciado no dispositivo em comentário, não pode e nem deve significar apenas o direito formal de invocar a jurisdição, mas o direito a uma decisão justa. Não fora assim aquela apreciação seria vazia de conteúdo valorativo.

12. Por certo que se há de perguntar como fica o juizo arbitral em face das considerações que acabamos de fazer. Fere ele o direito de acesso ao Poder Judiciário, ou não? De fato, a Lei 9.307, de 23.9.96, dispôs sobre a convenção de arbitragem e seus efeitos, assim como disciplinou o procedimento arbitral. Possibilita aos interessados se socorrerem da arbitragem, para compor litígios relativos a direitos patrimoniais disponíveis; conferiu maior autoridade à sentença arbitral, tornando desnecessária a sua homologação pelo Judiciário e ainda estimulou a criação de Tribunais Arbitrais. A lei não fere o princípio contido no dispositivo constitucional em exame, pois este o que impede é que a lei exclua da apreciação do Poder Judiciário qualquer lesão de direitos. Seria inconstitucional a lei se ela determinasse que certas questões teriam que ser submetidas ao juízo arbitral. Não é isso que ela faz. Apenas 
abre uma via especial de composição de litígio, a que as partes, em lide, recorrerão ou não. Se o fizerem, usaram de arbítrio, usaram de sua liberdade de disporem de seus interesses, como melhor lhe aprouverem. O caráter consensual da convenção arbitral mostra que ela não diz respeito à garantia do inc. XXXV do art. 5o, que, como diz Castro Nunes, supõe, ao seu natural, o desacordo das partes, assegurandolhes o acesso aos tribunais. Nesse sentido, já decidiu o STF (cf. Agr. Inst. 542.181GB, in RTJ 68/382, aí o parecer de Castro Nunes, e RE 56.851-GB, in RTJ 52/168). Ora, se as partes podem transigir, mediante acordo de vontade, até mesmo durante e depois do processo judicial, porque não poderia consentir na forma arbitral de decidir suas pendências? No fundo, o juízo arbitral é uma forma de valorizar a liberdade contratual.

\section{4 - Justiça igual para todos}

13. O direito fundamental de acesso à Justiça, como se vê pelas considerações supra, está resolvido do ponto de vista jurídico-constitucional. É, porém, profundamente triste constatar que, a despeito de assim resolvido, o nosso direito ainda não foi capaz de revogar a frase que Ovídio, poeta latino dos Tristes e das Metamorfoses, lançou há mais de dois mil anos, qual seja: Curia pauperibus clausa est (o tribunal, ou seja, a Justiça está fechada para os pobres). ${ }^{13}$ É que o acesso à Justiça não é só uma questão jurídico-formal mas é também e especialmente um problema econômico social, de sorte que sua aplicação real depende da remoção de vários obstáculos de caráter material, para que os pobres possam gozar do princípio de uma Justiça igual para todos. ${ }^{14}$ Ter acesso ao Judiciário sem a garantia de um tratamento igualitário não é participar de um processo justo. A igualdade é um elemento comum a toda concepção de Justiça, mormente na sua manifestação mais característica e mais relevante que é a igualdade perante o Juiz. Pois, é nesse momento que a igualdade ou a desigualdade se efetiva concretamente, como coisa julgada. O princípio da igualdade da Justiça só será respeitado, no sentido atual, se o juiz perquirir a idéia de igualdade real, que busca realizar a igualização das condições dos desiguais em consonância com o postulado da justiça concreta, não simplesmente da justiça formal. ${ }^{15}$

14. A cidadania não se realizará com a simples igualdade perante a lei, pois, como lembra Cappelletti, "hoje, é bem claro que tratar como iguais a sujeitos que econômica e socialmente estão em desvantagem não é outra coisa senão uma ulterior forma de desigualdade e de injustiça" ${ }^{16}$ Calamandrei ressalta numa passagem can-

13 Cf. Amores, lib. III, VIII, 55, in Mauro Cappelletti, Proceso, ideologias, sociedad, p. 155.

14 Temática muito discutida por Cappelletti, ob. cit. pp. 68 e ss.

$15 \mathrm{Cf}$. nosso "O advogado perante o princípio da igualdade", tese apresentada e aprovada na VI Conferência da O.A.B., realizada em Salvador, Bahia, de 17 a 22 de outubro de 1976, in Revista da Procuradoria Geral do Estado de Sāo Paulo. 9/141 e 142.

16 Cf. ob. cit., p. 67 
dente, citada por Cappelletti, a insuficiência dos velhos princípios sobre os quais se apóia a Justiça no processo judicial, tais como ne procedat iudex ex officio - ne iudex judicet in re sua - audiatur altera pars, que respondem a um processo liberal, mas não a um processo justo, para cuja efetivação não basta que ante a um juiz imparcial haja duas partes em contraditório, de modo que o juiz possa ouvir as razões de ambas; é necessário, além disso, que estas duas partes se encontrem entre si em condição de paridade não meramente jurídica e teórica, senão que exista entre elas uma efetiva paridade prática, o que quer dizer paridade técnica e também econômica; é que também diante da administração da justiça existe o perigo de que gravite sobre o pobre aquela maldição que pesa sobre ele cada vez que os ordenamentos democráticos se limitem a assegurar-lhe, a ele como a todos os outros cidadãos, as liberdades políticas e civis, as quais, em demasiadas ocasiões, quando lhes faltam os meios econômicos indispensáveis para valer-se praticamente daquelas liberdades, se resolvem para o pobre em coisa irrisória. ${ }^{17}$ Nessa concepção de um processo justo, o clássico direito de ação se transforma num direito de projeção social, não apenas como meio de recorrer ao Poder Judiciário para a defesa dos direitos individuais, mas para o estabelecimento de um verdadeiro direito material da justiça, que requer a remoção dos obstáculos econômicos e sociais que impedem o efetivo acesso à jurisdição. ${ }^{18}$

15. Em resumo, a questão dramática do acesso ao princípio da Justiça igual para todos consiste precisamente na desigualdade de condições materiais entre litigantes, que condicionam profunda injustiça àqueles que, defrontando-se com litigantes afortunados e poderosos, ficam na impossibilidade de exercer seu direito de ação e de defesa. Isso se torna ainda mais dramático com as consequiências processuais da revelia consubstanciada nas leis processuais, em virtude das dificuldades que o pobre tem de acesso até mesmo às fontes de informação que o alerte para os efeitos de sua inércia. É que um dos obstáculos sociais que impedem o acesso à Justiça está também na desinformação da massa da população a respeito de seus direitos. Isso é uma questão de educação, que promova o pleno desenvolvimento da pessoa e a prepare para o exercício da cidadania e sua qualificação para o trabalho, como determina formalmente a Constituição (art. 205), mas que a prática não consegue efetivar. A situação de miséria, despreparo e carência de milhões de brasileiros torna injusta e antidemocrática a norma do art. 30 da nossa Lei de Introdução ao Código Civil, segundo o qual ninguém se escusa de cumprir a lei, alegando que não a conhece. Essa regra é a legalização de um velho aforismo: ignorantia iuris non excusat, que Mauro Cappelletti increpa de ser uma fórmula clássica de um sistema não democrático, porque, diz ele, a realidade é que o rico pode eliminar a ignorância assegurando-se de serviços de consultores jurídicos, enquanto ela paralisa o pobre no exercício de seus direitos, quando não o coloca francamente à mercê de baixas especulações profissionais. Dá ele exemplo para a Itália, que calha bem ao nosso meio, onde, em

17 Cf. in Mauro Cappelletti, ob. cit., p. 116.

18 Cf. Hector Fix Zamudio. "La administración de justicia". Separata de Anuario Jurídico, VII - 1980, p. 87. 
certas regiões, é manifesto que o fenômeno de uma multissecular ignorância está na base de formas tradicionais e difundidas de bandidagem e de justiça pela própria mão feita fora e contra a Justiça estatal (regime de escravidão, de exploração de menores etc.), e, ainda acrescenta, que, tal como acontece aqui, é frequiente que os mais pobres nem sequer saibam da existência de certos direitos seus, e da possibilidade de fazê-los valer em juízo servindo-se do patrocínio gratuito, ${ }^{19}$ de defensores públicos.

16. A assistência jurídica integral e gratuita aos que comprovarem insuficiência de recurso configura um dos direitos individuais inscrito na Constituição (art. $5^{Q}$, LXXIV), como outras prestações positivas do Estado, procura realizar o princípio da igualização das condições dos desiguais perante a Justiça, mas temos que convir que ainda é um ideal longe de ser atingido, e sua insuficiência deixa o beneficiado em razoável desamparo, embora o sistema de defensorias públicas tenda ao aperfeiçoamento com a profissionalização específica e missioneira para o exercício desse mister. A velha e hoje ultrapassada fórmula de nomeação de advogados dativos transfere o tratamento desigual para eles, confrontando procuradores em situação de desigualdade. Com efeito, o patrocínio gratuito como dever honorífico de defender o pobre é uma mistificação, como nota Cappelletti, "que não prospera numa economia de mercado na qual uma prestação não retribuída está destinada a ser, na maior parte dos casos, de deficiente qualidade quando não possa ser, como de fato o é frequientemente, simplesmente recusada" ${ }^{20}$ Embora, na concepção da Constituição (art. 133), o advogado já não possa mais considerar-se um profissional tipicamente liberal, mas um colaborador ativo e indispensável ao julgador na solução justa, e não somente formal, das controvérsias, ${ }^{21}$ não será justo impor-lhe um ônus, o patrocínio honorífico, que deve caber ao sistema de prestaçōes positivas do Estado.

17. Não basta, porém, o poder público oferecer serviços de assistência jurídica aos necessitados para que se efetive na prática o direito de acesso à Justiça. Enquanto não se criarem as condiçōes econômicas e sociais indispensáveis ao gozo dos direitos fundamentais, sempre haverá dificuldades para a implementação do princípio da Justiça igual para todos, porque a relação de injustiça está na própria configuração da ordem social. Uma ordem social injusta não pode produzir um processo justo, nem, por certo, um sistema judicial de solução justa dos conflitos de interesse.

\section{5 - Acesso à Justiça e organização judiciária}

18. A organização judiciária é meio institucional preordenado para o exercício da prestação jurisdicional, que o Estado tem que pôr a serviço da cidadania. As instituições judiciárias, como qualquer instituição, constituem organizações fundadas numa idéia de obra a realizar-se. Não são entes estáticos. São, ao contrário, dinâmi-

19 Cf. ob. cit., p. 177.

20 Ob. cit., p. 111.

21 Cf. Hector Fix Zamudio, ob. cit., p. 92. 
cos, porque são entidades históricas que, como a história, hão de transformar-se para bem servir a comunidade As instituiçōes, adverte Maurice Hauriou, ${ }^{22}$ duram enquanto respondam às necessidades do meio social e segundo as idéias em que repousam estejam mais ou menos cerca da verdade e da justiça, pois, as instituições respondem a necessidades, prestam serviços; quando cessam de prestá-los, ou não os prestam devidamente, ou se voltam de preferência para seu interior, apegadas a interesses corporativos, correm o risco de deformar-se, tornando-se parasitárias, diz ele. Neste caso, diz ainda Hauriou, a confiança do público se aparta delas lentamente. Se sobrevivem algum tempo, é em virtude da velocidade adquirida, mas se encontram em transe de reforma ou de supressão.

19. Estamos todos conscientes de que o Poder Judiciário, como instituição pública governamental, não vem respondendo às necessidades da hora presente. Forjado no contexto do Estado liberal, não conseguiu transformar-se para acompanhar as novas exigências históricas. Encastelado no espírito individualista, continua um Poder passivo, à espera de que os sedentos de Justiça lhes mendigam a solução do seu caso. Aqui o Sermão da Montanha não tem acertado. Este diz: "Bem-aventurado os que têm fome e sede de justiça, porque eles serão fartos" (Mat. cap. 5, vers. 6). Não tem havido bem-aventurança, não por culpa da magistratura em si, mas das estruturas caducas e empedernidas. Não há nenhuma injustiça se lermos versículo bíblico às avessas: "Mal-aventurados os que têm fome e sede de justiça no Brasil, porque eles não serão fartos", pois que a solução é tão demorada que mais vale o dito de Ruy Barbosa de que "justiça atrasada não é justiça, mas injustiça qualificada e manifesta".

20. Todos estamos conscientes de que o Judiciário carece de profunda reforma, nāo só disso. Talvez precise mais ainda de ser repensado, para que passe a exercer novo papel histórico, desencastelando-se, para ir fartar a fome de justiça àqueles que não têm condições de ir às suas salas e palácios. Nesse sentido, são alvissareiras algumas experiências que estão sendo feitas de Juizados Itinerantes, no Estado do Amapá, sob a coordenação da Juíza Sueli Pereira Pini, sob três modalidades: Juizado Itinerante Fluvial (um barco com juiz, promotor, defensor e funcionários percorre o Rio Amazonas, atendendo a população ribeirinha); Juizado Itinerante Terrestre (um ônibus é transformado em sal de audiência e percorre bairros periféricos da capital); Juizado Volante (que atende, rapidamente, acidentes de trânsito sem lesão grave). Experiência semelhante também se faz em São Paulo em que Juizado Itinerante Permanente, em dois "trailers", percorre os bairros periféricos da capital para prestar serviços jurisdicionais a essas comunidades, já em fase de extensão a comarcas do interior do estado. Há também experiência semelhante no Espírito Santo e Minas Gerais. É também auspiciosa a generalização dos Juizados Especiais Cível e Criminal com base na Lei 9.099/95. Essas experiências constituem um avanço importante, não só pela prestação jurisdicional rápida, mas, sobretudo, porque geram uma ponderável reflexão sobre a função social do Juiz e a mudança de mentalidade dos tribunais. 
21. São avanços promissores, mas limitados, porque esses Juizados Especiais, mormente na sua forma itinerante, são uma pequena fração do trabalho da administração da Justiça e não podem ser encarados senão como medidas complementares. Sou, por outro lado, cético quanto ao futuro desses Juizados Especiais, se não se criarem carreiras de uma magistratura especializada para eles, porque o juiz tradicional não se afeiçoa a esse tipo de trabalho. Demais, enquanto esses Juizados Especiais, mormente os criminais, não passarem a funcionar, de alguma forma, vinte quatro horas por dia, para resolver os crimes de pequeno potencial ofensivo instantaneamente, por certo que os resultados serão muito aquém do desejável, especialmente porque os termos circunstanciados e os procedimentos deles resultantes já começam a ficar burocratizados, e já a morosidade chega a esses Juizados.

22. Enfim, se o Poder Judiciário deve ser mesmo a sede da cidadania e jurisdição, uma via de agitação da permanente da cidadania, como vaticina ilustre constitucionalista mineira, ${ }^{23}$ tem ele que sair do marasmo, e, para tanto, não bastam melhorias pontuais. É necessário, contudo, compreender a reforma no sentido muito mais amplo. Ela deve abranger todas as instituições envolvidas na administração da Justiça, o que envolve instituições policiais, ministério público, inclusive posturas de advogados, sistema carcerário, e especialmente a legislação processual, substituindo tecnicismo e fiç̧ões legais por formalidades simples e normas processuais ágeis e destinadas a eliminar sutilezas e chicanas. Um pouco de formalidades é absolutamente necessário para a proteção de direitos e a realização de um julgamento justo, mas o excesso de formalidades acaba resultando na violação de direitos a uma sentença em tempo hábil e num julgamento injusto.

\section{6 - Pontos da reforma judiciária}

23. Tem-se discutido muito a reforma do Judiciário. Há vários projetos em tramitação no Congresso Nacional. Temas polêmicos como súmulas vinculantes, controle externo do Judiciário agitam os espíritos. Não há tempo, neste final de exposição, para discutir esses e outros temas.

As súmulas vinculantes tolhem uma correta apreciação das alegações de lesão ou ameaça de direito que está na base do direito ao acesso à Justiça. Os prejuízos à cidadania são maiores do que os benefícios para a ordem judiciária. Uma providência que uma reforma do Judiciário deveria adotar, porque racional, seria declarar numa disposição simples: as leis e atos normativos perdem a eficácia a partir do dia seguinte ao da publicação da decisão definitiva que os tenha declarado inconstitucionais. Isso tanto para a declaração de inconstitucionalidade em ação direta como na via incidental, dando, dessa forma, efeito vinculante erga omnes a essa declaração só por si, suprimindo-se, em consequiência, o disposto no inc. X do art. 52 da Constituição.

O chamado controle externo peca pela má significação dessa expressão que traz a idéia de que um poder externo vai controlar o Poder Judiciário, o que seria um 
desastre. Isso não exclui a necessidade de um órgão não judiciário para o exercício de certas funções de controle administrativo, disciplinar e de desvios de condutas da magistratura. Órgão dessa natureza existe previsto em Constituições de vários países: Conselho Superior da Magistratura, na Itália (art. 105); França (art. 65); Portugal (art. 223); Espanha (art. 122); Turquia (arts. 143-144); Colômbia (art. 254-257); Venezuela (art. 217). Darei quatro exemplos:

Constituição italiana: art. 104. A magistratura constitui uma ordem autônoma e independente de cada um dos outros Poderes. O Conselho Superior da Magistratura é presidido pelo Presidente da República. Dele fazem parte de direito o primeiro presidente e o procurador geral da Corte de Cassação. Os outros componentes são eleitos por dois terços de todos os magistrados ordinários entre os pertencentes a várias categorias, e por um terço do Parlamento em sessão ordinária entre professores ordinários de universidades em matéria jurídica e advogados depois de cinco anos de exercício. O Conselho elege um vice-presidente entre os componentes designados pelo Parlamento. Os membros eletivos do Conselho têm mandato de quatro anos e não são imediatamente reelegíveis.

Constituição francesa: art. 65. O Conselho da Magistratura será presidido pelo Presidente da República. O Ministro da Justiça será, de pleno direito, seu vice-presidente. Poderá substituir o Presidente da República. O Conselho Superior se comporá, além disso, de novos membros designados pelo Presidente da República nas condições fixadas por uma lei orgânica. O Conselho Superior da Magistratura formulará propostas para as nomeações de magistrados do Tribunal de Cassação e para as de Primeiro Presidente do Tribunal de Apelação. Dará sua opinião, nas condições estabelecidas pela lei orgânica, sobre as propostas do Ministro da Justiça relativas às nomeações de outros magistrados. Será consultado sobre os indultos nas condições fixadas por uma lei orgânica. O Conselho Superior da Magistratura estatuirá como conselho de disciplina dos magistrados oficialmente designados. Neste caso, será presidido pelo Primeiro Presidente do Tribunal de Cassação.

Constituição portuguesa: art. 223. 1. O Conselho Superior da Magistratura é presidido pelo Presidente do Supremo Tribunal de Justiça e composto pelos seguintes vogais: a) dois designados pelo Presidente da República, sendo um deles magistrado judicial; b) sete eleitos pela Assembléia da República; c) sete juízes eleitos pelos seus pares, de harmonia com o princípio da representação proporcional. 2. As regras sobre garantias e incompatibilidades dos juízes são aplicáveis a todos os vogais do Conselho Superior da Magistratura. 3. A lei poderá prever que do Conselho Superior da Magistratura façam parte funcionários de justiça, eleitos pelos seus pares, com intervenção restrita à discussão e votação das matérias relativas à apreciação do mérito profissional e ao exercício da função disciplinar sobre os funcionários e justiça.

Constituição espanhola: Art. 122. 1.... 2. O Conselho Geral do Poder Judicial é o órgão de governo do mesmo. A lei orgânica estabelecerá seu estatuto e o regime de incompatibilidades de seus membros e suas funções, em particular em matéria de nomeação, acesso, inspeção e regime disciplinar. 3. O Conselho Geral do Poder Judicial será integrado pelo Presidente do Tribunal Supremo, que o presidirá, e por vinte membros nomeados pelo Rei por um período de cinco anos. Destes, doze entre 
juízes e magistrados de todas as categorias judiciais, nos termos que estabeleça a lei orgânica; quatro por proposta do Congresso de Deputados, e quatro por proposta do Senado, eleitos em ambos os casos por maioria de três quintos de seus membros, entre advogados e outros juristas, todos eles de reconhecida competência e com mais de quinze anos de exercício em sua profissão.

Esse tipo de órgão externo é benéfico à eficácia das funções judiciais, não só por sua colaboração na formulação de uma verdadeira política judicial, como também porque impede que os integrantes do Poder Judiciário se convertam num corpo fechado e estratificado. ${ }^{24}$ Sob outro aspecto, não é desprezível a idéia de que esse tipo de órgão contribua para dar legitimidade democrática aos integrantes do Poder Judiciário, cuja investidura não nasce da fonte primária da democracia que é o povo.

24. Gostaria apenas de mencionar mais dois pontos que me parecem fundamentais numa reestruturação do Judiciário: a descentralização e a criação de uma Corte Constitucional.

A descentralizaçāo há de ser geográfica e por especialização.

A descentralização geográfica significa a distribuição de juízes e tribunais no território do Estado. Ela é especialmente necessária na organização judiciária estadual, que é a que basicamente dirime conflitos de interesse com base no direito civil e no penal. Mas a justiça federal de primeiro grau comporta descentralização. Proposta minha perante a Comissão Afonso Arinos contemplava essa idéia. Mantinha o Supremo Tribunal Federal como tribunal superior da ordem judiciária brasileira, como uma espécie de tribunal da Federação, não teria, porém, competência em matéria constitucional, que caberia a um previsto Tribunal de Garantias Constitucionais, fora da estrutura do Poder Judiciário. Na organização da Justiça Federal Comum, a proposta previa um Superior Tribunal de Recursos e cinco Tribunais Federais de Recursos, um para cada região geoeconômica, o que, de certo modo, veio a ser contemplado na Constituição de 1988 (STJ e cinco TRF); para os Juízes Federais de primeiro grau, previam-se varas localizadas em circuitos judiciários no interior. A descentralização mais eficaz, a meu ver, estava prevista para o sistema judiciário dos Estados: I — o Tribunal de Justiça, como tribunal superior do sistema; II - Tribunais de Apelação, como tribunais de segunda instância, sendo um para cada região judiciária em que se dividisse o território estadual, tanto quanto possível, coincidente com suas regiões administrativas; III - juizes e tribunais de primeira instância, distribuídos nas comarcas e termos ou distritos em que se dividisse cada região do Estado. O Tribunal de Justiça, nesse esquema, que não precisaria ter número elevado de Desembargadores, seria tribunal da cúpula do Poder Judiciário do Estado, mas teria mais função política e de coordenação do que de um tribunal de julgamento de recursos, a não ser quando decisão de Tribunal de Apelação contrariasse dispositivo de contrato, convênio ou lei estadual, ou julgasse lei municipal válida em face de lei estadual, ou desse à lei estadual interpretação divergente

24 Assim se exprime H. Fix Zamudio, "Función del Poder Judicial en los sistemas constitucionales latinoamericanos". no volume com o mesmo título, Instituto de Investigaciones Jurídicas, p. 45. 
da que the fosse dada por outro Tribunal de Apelação ou do próprio Tribunal de Justiça. A carreira da magistratura estadual seria vinculada aos Tribunais de Apelação, portanto, seria regionalizada, sem prejuízo de transferência, a pedido, para outra região. A descentralização judiciária de primeiro grau seria feita por distritos, não só nas Capitais como também nas comarcas do interior, para contemplar povoações carentes de organização judiciária nas pequenas comunidades. A descentralização da segunda instância contribuirá para acelerar as decisões judiciais. Evita transportes de feitos a longas distâncias até o Tribunal competente sediado na Capital. Há aí uma economia importante de tempo, correspondente ao trânsito de longa distância. A descentralização geográfica, assim, contribui para levar a atividade jurisdicional para junto dos jurisdicionados, com grande benefício para a cidadania.

A descentralização por especialização significa criar juízos especializados, de primeira e de segunda instâncias. Já existe alguma coisa nesse sentido: juízo cível, juízo criminal, de falência etc. Poder-se-ia criar, especialmente na capital e nas grandes cidades, não apenas juízos de primeiro grau especializados: civil, família, comercial, criminal, acidentes, mas também de segundo grau. Por exemplo, a criação de uma Justiça Administrativa, como órgãos do Poder Judiciário, em todos os níveis, para solucionar litígios decorrentes de relações de trabalhos de servidores públicos com a entidade pública empregadora, incluindo um Superior Tribunal Administrativo, inserindo na sua competência a apreciação definitiva de inconstitucionalidade relacionada com a matéria de sua competência. Esse tipo de contencioso não prosperou entre nós porque era previsto fora da organização judiciária, mas se forem órgãos do Poder Judiciário não há por que não vingar, com bons resultados para 0 bom andamento da administração da Justiça.

25. Finalmente, naquela minha proposta perante a Comissão Afonso Arinos, num subtítulo sob a rubrica da defesa da Constituição, vinha o Cap. I sobre a Jurisdição Constitucional, onde se definia a problemática das inconstitucionalidades com a institucionalização do Tribunal de Garantias Constitucionais, com a competência para a ação de inconstitucionalidade por ação ou omissão; julgamento de recursos de inconstitucionalidades das decisões dos tribunais semelhantes as que hoje são objeto do recurso extraordinário, e julgamento de qualquer conflito de natureza constitucional. Sua competência corresponderia mais ou menos à do Supremo Tribunal Federal, hoje, mas seria composto de quinze membros, com mandato de doze anos, eleitos: cinco pelo Poder Legislativo, dois pelo Supremo Tribunal Federal e cinco pelo Conselho de Ministros, Conselho esse que estava também previsto na proposta.

26. Estou ainda convencido de que a criação de uma Corte Constitucional é conveniente numa reforma do Poder Judiciário. Contudo, não a proporia com a mesma competência sugerida naquela sugestão. Hoje, parece-me que a Corte Constitucional deveria ficar apenas com a competência para a apreciação e julgamento de ações diretas de inconstitucionalidade, por ação ou omissāo. É preciso reconhecer que o volume de ações diretas de inconstitucionalidade está afogando o Supremo Tribunal Federal, que praticamente está decidindo por medida liminar, o que, por certo, a médio prazo, acabará em seu descrédito. Ficaria o Supremo, pois, com a 
apreciação de inconstitucionalidade incidenter tantum, em grau de recurso extraordinário, enquanto a Corte se incumbiria do controle centralizado de constitucionalidade.

\section{7 - Conclusão}

27. Uma reforma judiciária não pode ter apenas a preocupação de aliviar o Poder Judiciário da carga de trabalho que o assoberba no momento, mediante forma de afastar de sua apreciação interesses que procuram o amparo jurisdicional. As discussões em torno do tema têm-se prendido muito a esse aspecto. Se há situações que comportam restrições, como o número excessivo de recursos ẹ a insistência do Poder Público de recorrer ao Judiciário em causas sucessivamente perdidas, o certo é que a tomada de consciência pela cidadania de seus direitos tende a buscar no Judiciário a sua satisfação, e essa é uma busca legítima, que não pode ser tolhida para melhorar a condição de trabalho do aparelho da Justiça.

28. Qualquer reforma do Judiciário, para ser legítima, há de estar fundamentada na ampliação do acesso da cidadania à Justiça, da melhoria dos serviços judiciários, da realização do processo justo. Do contrário, será um novo engodo ao povo. 